\title{
The first Symphytognathidae (Arachnida: Araneae) from Argentina, with the description of a new species of Anapistula from the Yungas mountain rainforest
}

La primera Symphytognathidae (Arachnida: Araneae) para Argentina, con la descripción de una nueva especie de Anapistula para la selva de montaña Yungas

\author{
GONZALO D. RUBIO $1,{ }^{*} \&$ ALDA GONZÁLEZ ${ }^{2}$
}

${ }^{1}$ CONICET Córdoba, Diversidad Animal I, Facultad de Ciencias Exactas, Físicas y Naturales, Universidad Nacional de Córdoba, Av. Vélez Sarsfield 299, X5000JJC Córdoba, Argentina

2 CONICET La Plata, Centro de Estudios Parasitológicos y de Vectores (CEPAVE), Universidad Nacional de La Plata (UNLP), Calle $2 \mathrm{~N}^{\circ}$ 584, 1900 La Plata, Argentina

* Corresponding author: grubio@conicet.gov.ar

\begin{abstract}
The spider family Symphytognathidae is reported from Argentina for the first time. Anapistula yungas, a new species of this family is described and illustrated. The specimen was collected during an ecological study of biodiversity in different sites from northwestern Argentina. Dichotomous key to Neotropical female species of genus Anapistula is provided.
\end{abstract}

Key words: Anapistula yungas, new record, Salta, taxonomy, Yungas eco-region.

\section{RESUMEN}

La familia de arañas Symphytognathidae es registrada por primera vez en Argentina. Anapistula yungas, una nueva especie de esta familia, es descripta e ilustrada. Los especímenes fueron colectados durante un estudio ecológico de biodiversidad en diferentes sitios del noroeste de Argentina. Se proporciona una clave dicotómica para hembras de las especies neotropicales del género Anapistula.

Palabras clave: Anapistula yungas, ecorregión Yungas, nuevo registro, Salta, taxonomía.

\section{INTRODUCTION}

The family Symphytognatidae was established by Hickman (1931) for the Australian species Symphytognatha globosa Hickman, extraordinary for its tiny size (Forster \& Platnick 1977). This spider family is diagnosed by the following combination of characters: the female pedipalp is either reduced to a unisegmented lobe or absent, the chelicerae are more or less fused, the labium is much wider than long, and the sternum is broadly truncate posteriorly (Forster \& Platnick 1977). At present Symphytognathidae includes seven genera (Anapistula Gertsch, Anapogonia Simon, Crassignatha Wunderlich, Curimagua Forster \& Platnick, Globignatha Balogh \& Loksa, Patu Marples, and Symphytognatha Hickman) and 62 species have been described worldwide (Cardoso \& Scharff 2009, Lin \& Li 2009, Platnick 2009).
The genus Anapistula can be separated from all other symphytognathid genera by the presence of an only slightly elevated pars cephalica and four eyes in two diads (the only exception is Anapistula boneti Forster with six eyes) (Forster \& Platnick 1977, Harvey 1998). It currently comprises 20 species (Cardoso \& Scharff 2009) of which seven are Neotropical, and only one of them (Anapistula secreta Gertsch) with a wide distribution from southern USA to Colombia and Brazil (Rheims \& Brescovit 2003, Platnick 2009). These spiders are rarely collected in large numbers owing to their minute size and occurrence in leaf litter habitats (Miller et al. 2009), and are usually captured only when specifically searched for or when Berlese funnels, Winkler extractors or pitfall traps are used (Rheims \& Brescovit 2003).

This is the first record of a spider of the family Symphytognathidae from Argentina 
and, according to the morphology of the female genitalia, the specimen is here postulated to represent a new species of the genus Anapistula. For comparative purposes, a dichotomous key to Neotropical female species of the genus is also given here.

\section{METHODS}

The material was collected during an ecological study of biodiversity in different sites in northwestern Argentina, using a G-Vac method to collect spiders from vegetation. This method consist of a vacuum cleaner Sthil ${ }^{\circledR}$ with tube of $110 \mathrm{~cm}$ of longitude and 12 $\mathrm{cm}$ of diameter (flow $710 \mathrm{~m}^{3} \mathrm{~h}^{-1}$ ), and each sample is the suction of the vegetation in an area of a square meter during one minute. The vegetation in this place is rainforest, and corresponds to the Yungas eco-region (Brown et al. 2002).

The description and terminology follow mainly Tong \& Li (2006). Female genitalia was observed and illustrated without dissect the epigynum from the specimen and after cleared in clove oil. The photos and illustrations were prepared from digital photographs captured using a Sony DSC-W290 camera attached to a Leica MS5 stereomicroscope. All measurements were taken with a micrometer ocular and are in millimeters.

The specimen examined is deposited in the Museo de La Plata, Argentina (MLP, curator L. Pereira).

\section{RESULTS}

Symphytognathidae Hickman, 1931

Anapistula Gertsch, 1941

Anapistula yungas sp. nov. (Figs. 1A-D)

\section{Type material}

Holotype (MLP 17 927): female from ARGENTINA: Salta Province, road to El Carmen (Camino de Cornisa) (24 $31^{\prime}$ S, 65 $21^{\circ}$ ' W), 27 April 2006, G. Rubio coll.

\section{Etymology}

The specific name, yungas, is a noun in apposition after the eco-region to which the type locality belongs.

\section{Diagnosis}

The female genitalia closely resembles that of $A$. secreta Gerstch by having the median epigynal duct reaching to the anterior tip of spermathecae (see Gertsch 1941, figs. 14-17), but it differs from that species because their length is the same as that of the spermathecae diameter, and it lacks the small vesicular projections on the spermathecae (Fig. $1 \mathrm{E}$ and $1 \mathrm{~F})$. Other important characters include the proportionally bigger globular spermathecae than the rest members of genus Anapistula.

\section{Description female (Holotype)}

Total length, not including chelicerae, 0.57. Carapace 0.25 long, 0.25 wide, 0.10 high. Opisthosoma 0.35 long, 0.35 wide, 0.17 high. Body without markings, color entirely pale yellow except for a black ring surrounding the eyes, and sclerotised internal genitalia. Carapace relatively low, with a setae at level of eyes, at middle (Figs. 1A and 1B). Anterior margin of clypeus with a row of setae. Cephalic part only slightly lower than thoracic part; part cephalic only slightly lower than part thoracic; lateral margins evenly rounded. Four eyes present in two diads, surrounded by darker rings, distance between diads 0.07 wide; anterior eyes larger than posteriors (Figs. 1A and 1B). Clypeus wide. Chelicerae slightly fused near their base, each with two sharp teeth near the base of the fang (Figs. 1H and 1I). Labium wider than long distinctly. Sternum posteriorly truncate, slightly longer than wide (Fig. 1C). Palp completely absent. Legs pale yellow, clothed with setae and bristles, each patella with a long distally-dorsal spine; joint inflexible between tarsus and metatarsus (Fig. 1D). Three tarsal claws, all of which appear smooth (Fig. 1G). Femur I 0.25 long, tibia I 0.15 long, metatarsus + tarsus I 0.32 long; femur II 0.22 long, tibia II 0.17 long, metatarsus + tarsus II 0.25 long; femur III 0.20 long, tibia III 0.13 long, metatarsus + tarsus III 0.28 long; femur IV 0.21 long, tibia IV 0.16 long, metatarsus + tarsus IV 0.30 long. Leg formula: I-IV-II-III. Opisthosoma without scute, covered with long smooth setae, globular, as long as wide (Figs. 1A-D). Book lungs not visible. Anterior spinnerets slightly larger than posteriors; median spinnerets not visible; colulus absent (Fig. 1C). Epigynum not sclerotized, two large globular spermathecae sclerotized, of which connected by relatively short lateral branches to median duct; bases of copulatory duct with a small anterior swelling (Fig. 1E). Distance between spermathecae 0.04 long.

Male. Unknown. 

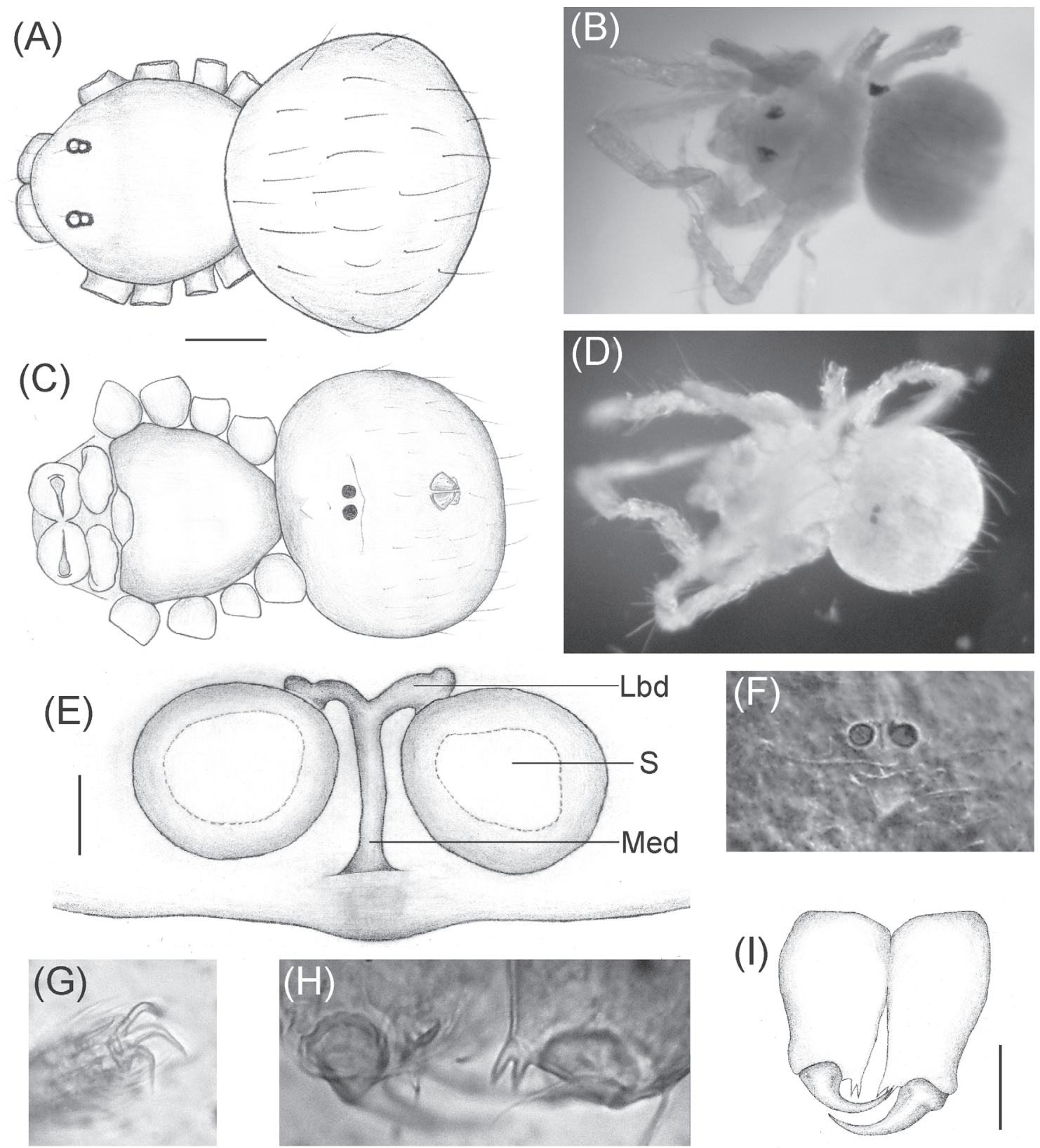

Fig. 1: Anapistula yungas sp. nov. holotype female (MLP 17927): (A-D), body view (A-B, dorsal; C-D, ventral); (E-F), cleared epigynum (ventral view); (G), tarsal claws; (H-I), chelicerae (frontal view). Lbd = lateral branch of epigynal duct; Med = median epigynal duct; $\mathrm{S}=$ spermathecae. Scale bars = $0.10 \mathrm{~mm}(\mathrm{~A}, \mathrm{C}) ; 0.05 \mathrm{~mm}(\mathrm{E}, \mathrm{I})$.

Anapistula yungas sp. nov. hembra holotipo (MLP 17927): (A-D), vista del cuerpo (A-B, dorsal; C-D, ventral); (E-F), epiginio aclarado (vista ventral); $(\mathrm{G})$, uñas tarsales; $(\mathrm{H}-\mathrm{I})$, quelíceros (vista frontal). Lbd $=$ rama lateral del ducto del epiginio; $\mathrm{Med}=$ ducto medio del epiginio; $\mathrm{S}=$ espermateca. Escala de barras $=0.10 \mathrm{~mm}(\mathrm{~A}, \mathrm{C}) ; 0.05 \mathrm{~mm}(\mathrm{E}, \mathrm{I})$.

\section{Remarks}

This species is currently represented only by the holotype which was captured with more than 3,300 spiders obtained in winter and autumn expeditions.

\section{Natural history}

The specimen was collected by a G-Vac method from low vegetation less than one meter from the forest floor, in rainforest at $1,700 \mathrm{~m}$ altitude. 


\section{Distribution}

The new species Anapistula yungas is known only from Salta Province, Argentina.

\section{Key to Neotropical female species of Anapistula}

1. Ventral atrium in the posterior region of the epigynum present (Rheims \& Brescovit 2003 , figs. $16,18,21)$ [2]

- Ventral atrium in the posterior region of the epigynum absent (Fig. 1E) ................. [4]

2. Large atrium, much larger than the spermathecae (Rheims \& Brescovit 2003, figs. 16, 18)

- Small atrium, same size or smaller than the spermathecae (Rheims \& Brescovit 2003, fig. 21) (Brazil: Rio Grande do Sul) .......... A. ybyquyra Rheims \& Brescovit 2003

3. Lateral branches of epigynal duct larger than the radius of spermathecae (Rheims \& Brescovit 2003, fig. 16) (Brazil: Mato Grosso do Sul, Rio de Janeiro) ................... A. aquytabuera Rheims \& Brescovit 2003

- Lateral branches of epigynal duct shorter than the radius of spermathecae (Rheims \& Brescovit 2003, fig. 18) (Brazil: São Paulo)

A. pocaruguara Rheims \& Brescovit 2003

4. Spermathecae with small lateral vesicular projections (Forster \& Platnick 1977, fig. 19; Rheims \& Brescovit 2003, fig. 14) ..... [5]

- Spermathecae without small lateral vesicular projections (Fig. 1E) (Argentina: Salta Province) .

A. yungas sp. nov.

5. Median epigynal duct longer than the spermathecae (Forster \& Platnick 1977, fig. 19) (USA to Colombia, Bahamas Is., Jamaica, Brazil) ...... A. secreta Gertsch 1941

- Median epigynal duct shorter than the spermathecae (Rheims \& Brescovit 2003, fig. 14) (Brazil: Amazonas) .. A. ayri Rheims \& Brescovit 2003

\section{DISCUSSION}

Spider fauna in subtropical rainforests of the Neotropical region is not yet well known, especially in the Argentinean where systematic fieldwork were not undertaken until recently (Rubio et al. 2008). However, in Argentinean Yungas rainforest, other arthropod fauna has only received attention during the last decade (Cuezzo et al. 2007), but undoubtedly many species remain to be found and new taxa discovered. This mountain rainforests are usually isolated from similar ecosystems by steep terrain and intervening lowlands with contrasting climates (Brown et al. 2002), and are very important areas since to have high species endemism (Cuezzo et al. 2007).

In the main, the Neotropical species of Anapistula are from Brazil (see key above and Rheims \& Brescovit 2003, fig. 23). The new species $A$. yungas is the first symphytognathid to be recorded and described from Argentina, and their importance is increased by the relict size of the rainforests environment from Argentina and for the scarce knowledge that one has of the genus.

\section{ACKNOWLEDGMENTS}

The manuscript was benefitted from comments from two anonymous reviewers and the RChHN editor. Moreover, we want to thank to Mark S. Harvey (Western Australian Museum, Australia), Shu-Qiang Li (Institute of Zoology, Chinese Academy of Sciences, China) and Antonio Brescovit (Instiuto Butantan, São Paulo, Brazil) for make helpful comments and corrections on the manuscript; to José A. Corronca (IEBI-Universidad Nacional de Salta, Argentina) for his assistance and the possibility of carrying out the samplings, and Diana Lopez Lezama (CEPAVE, Argentina) for assistance in the microscopy observations. This work was supported by the scholarship research given to G.D.R. by CONICET.

\section{LITERATURE CITED}

BROWN AD, A GRAU, T LOMÁSCOLO \& NI GASPARRI (2002) Una estrategia de conservación para las selvas subtropicales de montaña (Yungas) de Argentina. Ecotropicos 15: 147-159.

CARDOSO P \& N SCHARFF (2009) First record of the spider family Symphytognathidae in Europe and description of Anapistula ataecina sp. n. (Araneae). Zootaxa 2246: 45-57.

CUEZZO F, M LIZARRALDE DE GROSSO, F NAVARRO \& C SZUMIK (2007) Endemic insects from the Yungas of Argentina. Zootaxa 1576: 6367.

FORSTER RR \& NI PLATNICK (1977) A review of the spider family Symphytognathidae (Arachnida, Araneae). American Museum Novitates 2619: 129.

GERTSCH WJ (1941) Report on some arachnids from Barro Colorado Island, Canal Zone. American Museum Novitates 1146: 1-14.

HARVEY MS (1998) A review of the Australasian species of Anapistula Gertsch (Araneae: Symphytognathidae). Records of the Western Australian Museum 19: 111-120. 
HICKMAN VV (1931) A new family of spiders. Proceedings of Zoological Society of London 1931: 1321-1328.

LIN Y \& SQ LI (2009) First described Patu spiders (Araneae, Symphytognathidae) from Asia. Zootaxa 2154: 47-68.

MILLER JA, CE GRISWOLD \& C MIN YIN (2009) The symphytognathoid spiders of the Gaoligongshan, Yunnan, China (Araneae, Araneoidea): Systematics and diversity of microorbweavers. ZooKeys 11: 9-195.

PLATNICK NI (2009) The World Spider Catalog, Version 9.5. American Museum of Natural History, New York. URL: http:// research.amnh.org/entomology/spiders/ catalog/INTRO1.html (accessed May 01, 2009).
RHEIMS CA \& AD BRESCOVIT (2003) Description of six new species of Anapistula Gertsch (Araneae, Symphytognathidae) from Brazil. Bulletin of the British Arachnological Society 12: 324-330.

RUBIO GD, JA CORRONCA \& MP DAMBORSKY (2008) Do spider diversity and assemblages change in different contiguous habitats? A case study in the protected habitats of the Humid Chaco ecoregion, north-east Argentina. Environmental Entomology 37: 419-430.

TONG YF \& SQ LI (2006) Symphytognathidae (Araneae), a spider family newly recorded from China. Zootaxa 1259: 33-38. 
